\title{
Absorption of protein digestion products: A review
}

\author{
D. M. MATTHEWS AND LEONARD LASTER
}

From the Department of Chemical Pathology, Westminster Medical School,
London, and the Gastroenterology Unit, National Institute of Arthritis and
Metabolic Diseases, National Institutes of Health, Bethesda, MD., U.S.A.

Each major phase in the evolution of our present concept of the absorption of proteins and their digestion products has been initiated by an improvement in analytical techniques or experimental methods.

Before 1900, it was thought that the final products of protein digestion were proteoses and peptones, and it seemed likely that proteins were absorbed in these forms. Then Cohnheim (1901) discovered an intestinal enzyme, 'erepsin', that catalysed the hydrolysis of these larger protein breakdown products to amino-acids. This was followed by the demonstration that amino-acids were present in the small intestine during protein digestion (Kutscher and Seemann, 1901; Abderhalden, Körösy, and London, 1907), that animals could live on diets containing only hydrolysed protein (Loewi, 1902; Henderson and Dean, 1903) and could utilize amino-acids given intravenously (Buglia, 1912), and that there was a rise in the non-protein nitrogen of the blood during the absorption of protein, protein hydrolysates, or amino-acids (Cathcart and Leathes, 1906; Folin and Denis, 1912). These observations suggested that proteins were absorbed from the gut and transported to the tissues as amino-acids, but since the analytical methods then available were not sufficiently specific to show unequivocally the presence of free amino-acids in the bloodstream, it was possible to maintain that amino-acids might be synthesized into protein while passing through the intestinal wall and reach the tissues mainly in this form (Abderhalden, 1912).

In 1912, Van Slyke and Meyer, using the recently developed nitrous acid method, showed that there was a large rise in the amino-nitrogen of mesenteric and peripheral blood during the absorption of alanine and after feeding protein, and investigated the metabolic fate of absorbed amino-acids (Van Slyke and Meyer, 1912; 1913). Abel, Rowntree, and Turner (1914) obtained free amino-acids from the blood by vividialysis, and showed that they increased after a protein meal. This work laid the foundation for the theory that protein was completely hydro- lysed within the lumen of the gut, and that the constituent amino-acids were absorbed into the bloodstream by simple diffusion (e.g., Verzár and McDougall, 1936). This theory, though based on evidence that is now seen to be incomplete (e.g., Dent and Schilling 1949; Fisher, 1954) seemed adequate to explain nearly all the older observations and dominated the field for many years.

Further advances began in 1951, when it was shown by means of stereochemically specific methods that the L-isomers of many amino-acids were preferentially absorbed, which could not readily be explained if absorption were by simple diffusion. The development of techniques for studying absorption by isolated intestine in vitro made it possible to show that L-amino acids were actively transported by the small intestine, and since this time there has been great progress in knowledge of the mechanisms of absorption of protein digestion products. This paper gives an account of modern views on this subject and includes a brief description of the experimental methods which have contributed most to advances in the field.

\section{TRANSPORT ACROSS THE INTESTINAL WALL}

During absorption, a substance is removed from the intestinal lumen, transported across the intestinal wall and enters the blood or lymph. No single experimental technique will provide information on all these processes, nor are they all completely elucidated in any instance. Much of the recent work on intestinal absorption has concerned the mode of transport across the cells of the intestinal mucosa. The passage of substrates across the membranes of the mucosal cells is a special example of the general process of membrane transport, a subject that has been reviewed by Rosenberg (1954), Berliner (1959), and Christensen (1960). The structural features of the intestinal wall and their relation to the processes of absorption, and the nature of the mucosal barrier, are discussed by Laster and Ingelfinger (1961) and by Wilson $(1962 ; 1964)$. 
Transport phenomena may be classified and defined in many different ways, but it is convenient and simple to follow Crane (1960) in distinguishing two main modes of transport.

ACTIVE TRANSPORT Active transport is dependent on the expenditure of metabolic energy, and is capable of moving substances across a membrane against a chemical or electrical gradient. Experimentally, the clearest evidence for active transport is the demonstration of transport against an electrochemical gradient (i.e., 'uphill' transport). Confirmatory evidence is provided by showing that the transport is abolished by interfering with the metabolic energy supply, by such means as anoxia or metabolic inhibitiors.

PASSIVE TRANSPORT Passive transport does not require the expenditure of metabolic energy, and occurs in the same direction as the electrochemical gradient that exists across the membrane. The characteristics of passive transport are determined by the nature of the molecules transported and the properties of the membrane involved. The least complex example of passive transport is 'simple diffusion' which occurs when a membrane is freely permeable to the solute molecules. In simple diffusion, the rate of transport is directly proportional to the concentration difference across the membrane-an uncommon situation in biological systems. There are comparatively few nutrients which are now believed to be absorbed by simple diffusion. In a special form of passive transport known as 'facilitated diffusion', the rate of transport is much greater than that which would be expected on the basis of the known physical properties of the system. Certain features are common to both facilitated diffusion and active transport. These include selective transport of one substance as compared with another of similar molecular size, competition for transport between structurally similar molecules, amd lack of proportionality between transport rate and the concentration difference across the membrane. In both active transport and facilitated diffusion, the transport rate tends to approach a limiting value as the concentration of the transported substance is increased and the transport mechanism becomes saturated. Active and passive transport are probably not mutually exclusive, nor are they necessarily entirely distinct processes. Thus it is quite probable that a substance may be transported by both processes simultaneously.

The mechanisms responsible for active transport and facilitated diffusion are poorly understood. A hypothesis frequently used in discussions of active transport is that of the 'shuttling carrier': that the cell membrane contains a carrier which can pick up a substance on one side and release it on the other, the system being 'driven' by metabolic energy. A similar hypothesis might explain facilitated diffusion, only in this case the system would not be driven by metabolic energy. Other hypotheses of active transport are described by Ussing (1957) and Christensen $(1960 ; 1962)$.

The view is sometimes expressed that active transport mechanisms capable of moving solutes against concentration gradients are unlikely to be important in absorption from the intestine, since, under physiological conditions, solutes pass from the lumen of the gut to the blood in the direction of a concentration gradient. Active transport, however, can probably greatly accelerate the movement of substances which would diffuse only slowly through the intestinal wall. The diffusion of amino-acids through non-living membranes is known to be unusually slow (Schmengler, 1933). It has also been suggested that active transport may be important in limiting back-diffusion from the blood into the intestinal lumen (Booth and Kanaghinis, 1963).

\section{METHODS OF INVESTIGATING INTESTINAL ABSORPTION}

METHODS in vitro Much of the recent work on the absorption of amino-acids and peptides has been carried out using isolated intestine in vitro. Methods in vitro are less 'unphysiological' than would appear at first sight (Smyth, 1961a), and provide information difficult or impossible to obtain in any other way.

Early preparations of intestine in vitro did not give very satisfactory results, probably owing to inadequate oxygenation of the mucosa. The first satisfactory preparation in vitro was that of Fisher and Parsons (1949), in which the lumen of a length of rat small intestine was perfused with oxygenated saline while the serosal surface was bathed in the same solution. A simplified apparatus was devised by Wiseman (1953) and used to demonstrate the active transport of amino-acids; Darlington and Quastel (1953) described an apparatus based on similar principles.

The simplest and most widely used method in vitro is that using everted sacs of small intestine (Wilson and Wiseman, 1954). A length of small intestine from a small animal, usually a rat or hamster, is everted with a glass rod so that the mucosal surface is on the outside. Sacs are made from the everted intestine and filled with KrebsRinger saline, or other appropriate solution (usually $0.5-1 \mathrm{ml}$.); this is termed the 'serosal fluid'. 


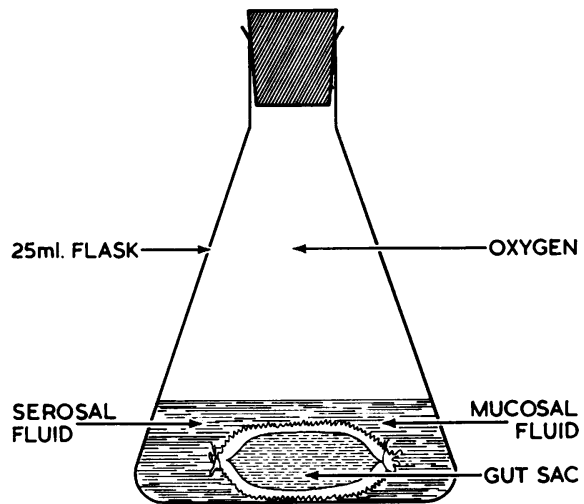

FIG. 1. A 'simple sac' of everted intestine.

Each sac is placed in a flask containing saline (usually $5-10 \mathrm{ml}$.); this is termed the 'mucosal fluid', and incubated under oxygen with gentle shaking (Fig. 1). The preparation remains active for at least one hour at $37^{\circ} \mathrm{C}$. Eversion of the sac, with slight distension, stretches the mucosa and improves its oxygenation; while the small volume of the fluid within the sac causes transport of any solute from the mucosal to the serosal side to produce a relatively large increase in concentration in the serosal fluid. In investigation of active transport, the experiment is usually begun with equal concentrations of the test substance in mucosal and serosal fluids. If at the end of the experiment, the concentration in the serosal fluid has risen and that in the mucosal fluid has fallen, it can usually be taken that transport against a concentration gradient has occurred (Fig. 2).
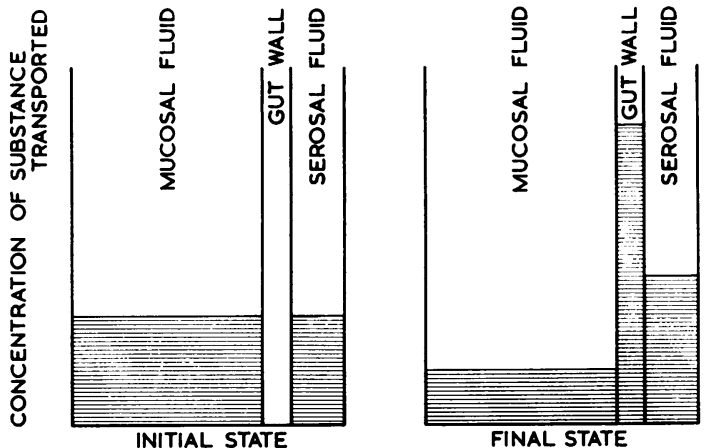

FIG. 2. Transport against a concentration gradient. At the start of the experiment, the mucosal and serosal concentrations of the substance transported, e.g., an aminoacid or glucose, are equal. At the end of the experiment, the substance has been accumulated to a high concentration in the gut wall and much of it has been transported across the wall into the serosal fluid, so that the final concentration in the serosal fluid is higher than that in the mucosal fluid.
This is, however, only true if the serosal volume has increased (as it usually does, owing to water transport) or at least remained constant; in other words, if the increase in concentration of the solute on the serosal side cannot be accounted for by net water movement in the opposite direction, with retention of solute in the serosal fluid. Transport of solutes out of the mucosal fluid and into the serosal fluid can be measured from the changes in concentration in these fluids, and from their initial and final volumes.

In the technique of Crane and Wilson (1958), the everted sac is cannulated at one end (Fig. 3). With this preparation, the time course of transport into the serosal fluid can be followed by serial sampling, and it is possible to observe the effect of altering conditions during the experiment. Thus a control period may be followed by a second period during

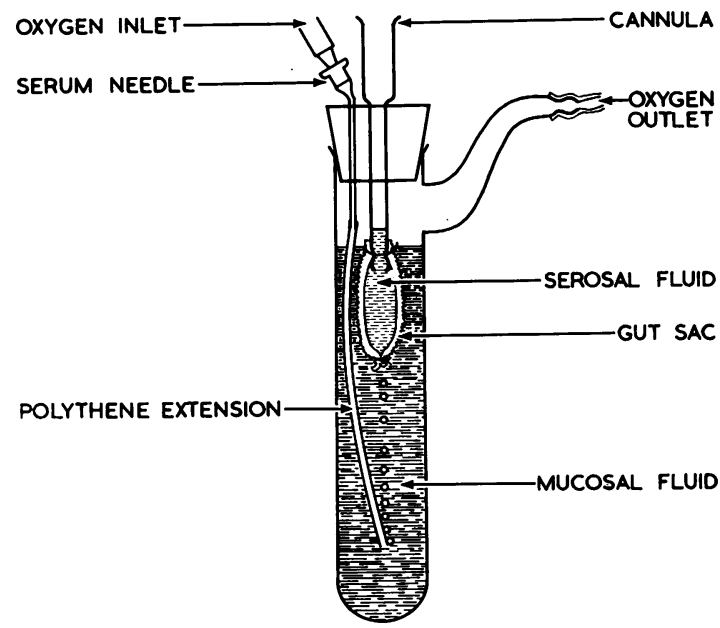

FIG. 3. Diagram of the apparatus of Crane and Wilson (1958) as modified by Crampton and Matthews (1964). The wide oxygen outlet prevents blockage by fragments of desquamated mucosa, which sometimes occurs in the original apparatus.

which some additional factor expected to influence transport is introduced (Matthews and Laster 1965b).

In a third technique in vitro, uptake of substances by the intestinal wall or its substructures is measured. Strips or rings of intestine, sheets of mucosa, and isolated villi have been used (e.g., Agar, Hird, and Sidhu, 1954; Crane and Mandelstam, 1960). Such experiments give useful information, as in many cases the mechanism of concentration by the mucosal cells is an essential part of that for transport across the intestinal wall. Such techniques have the advantages that results are more reproducible and the physical system is simplified; in sac preparations the substance transported must diffuse across the 
subepithelial and muscle layers before reaching the serosal fluid.

METHODS in vivo These are of two main types: those in which disappearance of a substance from the lumen of the gut is studied, and those involving analyses of the blood or lymph.

The simplest procedure is to inject a solution of the substance into tied intestinal loops (e.g., Verzár and McDougall, 1936; Gibson and Wiseman, 1951) and sample the contents at the end of the experiment. As the absorptive capacity of the intestine varies with site, it is not possible to compare the influence of different conditions on absorption in different loops, unless the loops are adjacent and kept very short. By cannulation of both ends of a loop of intestine, the same segment can be used in successive experiments under different conditions (Sols and Ponz, 1947; Horváth and Wix, 1951), and by continuous perfusion with recirculation from a reservoir, 'perfusion in situ' (e.g., Sheff and Smyth, 1955; Fullerton and Parsons, 1951) the concentration of the substance being absorbed can be controlled, which is an advantage in experiments on the kinetics of absorption. Whenever such techniques are used, it must be remembered that the information they give is limited, and that the rate of disappearance of a substance from the gut lumen does not necessarily represent its rate of entry into the blood or lymph. Substances may disappear from the lumen of the gut not because of absorption but as the result of chemical or bacterial action within the lumen. They may also be taken up and retained in the wall for an appreciable period, or extensively metabolized within the wall, and some substances disappear from the lumen in one form and appear in the blood in another.

Analyses of the portal and arterial blood during absorption also require critical interpretation. An indwelling portal cannula may be used in the unanaesthetized animal (London, 1935; Dent and Schilling, 1949; Denton, Gershoff and Elvehjem, 1953), or the blood may be sampled in an acute experiment. In the absence of an estimate of portal blood flow, no quantitative estimate of absorption rate is obtained. Since alterations in the composition of the blood during absorption are contributed to by the tissues, even the qualitative interpretation of the data has certain pitfalls (Dent and Schilling, 1949; Fisher, 1954). To overcome these difficulties, it is possible to tie off a loop of intestine, cannulate the vein draining it, and collect all the blood leaving the loop during the experimental period (Matthews and Smyth, 1954). The blood is not returned to the animal, so that the absorbed substance does not appear in the arterial blood supply to the loop. In this way the total amount of substance absorbed into the blood can be compared with the amount disappearing from the intestinal lumen.

Many methods which have not contributed appreciably to the study of the absorption of protein digestion products have been omitted from this account. More general or more detailed accounts have been published by Crane (1960), Quastel (1961), Smyth (1961b), Wiseman (1961), and Wilson (1962).

THE FORMS IN WHICH PROTEINS AND THEIR DIGESTION PRODUCTS ARE ABSORBED

During the digestion of a protein meal, the intestinal tract contains a mixture of amino-acids, peptides, and whole or partially digested proteins, so that it is possible that any or all of these substances might be absorbed. The absorption of each group of substances will be dealt with in separate sections, though it may be said at the outset that there is little doubt that nearly all the ingested protein enters the blood as amino-acids, regardless of the form in which it leaves the intestinal lumen.

THE ABSORPTION OF AMINO-ACIDS

APPEARANCE IN THE BLOOD There is a large rise in the individual amino-acids of portal and peripheral blood during absorption of a protein meal (e.g., Dent and Schilling, 1949; Denton, Gershoff, and Elvehjem, 1953; Denton and Elvehjem, 1954; Stein, Bearn, and Moore, 1954; Longenecker and Hause, 1959). The amino-acid pattern of this increase bears some relationship to the composition of the protein fed, but exact correspondence is not to be expected, as the amino-acid composition of the intestinal contents is not dependent solely on the composition of the ingested protein, and is probably substantially modified by the hydrolysis of endogenous proteins derived from enzymes, mucus, and desquamated epithelial cells (Nasset, 1957). Other factors which may modify the amino-acid pattern appearing in the blood are differences in the rates of absorption of individual amino-acids, and differences in their rates of uptake by the tissues, which are affected by cellular requirements and other factors (Longenecker and Hause, 1959).

Fisher (1954) criticized the hypothesis that the bulk of the ingested protein appeared in the bloodstream as amino-acids, pointing out that the rate of hydrolysis of proteins by known digestive enzymes in vitro was so slow that it seemed unlikely that they could be completely hydrolyzed to amino-acids in vivo and absorbed in this form. However, large quantities of amino-acids have been found in the gut 
within a short time of feeding protein (Wright and Wynn, 1951), and work in man (Crane and Neuberger, 1960; Crane, 1961) suggests that protein is hydrolyzed vary rapidly. In spite of this, Fisher's arguments have received some support from the demonstration (referred to later) that the final stages of hydrolysis take place, at least in part, in the cells of the intestinal mucosa. The idea that proteins are absorbed into the blood as amino-acids has also been criticized on the grounds that the concentration of amino-acids in portal blood during protein absorption is too low to account for absorption entirely in this form. Dent and Schilling (1949) showed that this criticism was invalid for the dog if the large volume of the portal blood flow was considered. In man, if one assumes a portal plasma flow of 1 litre per minute, and an arterio-portal amino-acid concentration difference of $4 \mathrm{mg}$. $\alpha$-amino $N$ per $100 \mathrm{ml}$., it can be calculated that amino-acids equivalent to approximately $15 \mathrm{~g}$. of protein per hour could be transported from the gut. It is likely that the portal flow increases during digestion, and that the arterio-portal concentration difference can exceed $4 \mathrm{mg}$. when large amounts of proteins are fed, so that it does not appear that there is any difficulty in accounting for transport from the gut entirely in the form of amino-acids.

EVIDENCE FOR A SPECIAL ABSORPTIVE MECHANISM Most of the earlier work on the absorption of aminoacids was interpreted as showing that this was due to simple diffusion (e.g., Chase and Lewis, 1934; Andrews, Johnston, and Andrews, 1936; Kratzer, 1944). Höber and Höber (1937), however, found that the absorption of amino-acids was much faster than that of other compounds of similar molecular size, and that the rate of absorption approached a limiting value as the concentration in the intestinal lumen was increased, and Schofield and Lewis (1947) reported that $\mathrm{L}$-alanine was absorbed more rapidly than D-alanine. Then Wiseman and others (Elsden, Gibson and Wiseman, 1950; Gibson and Wiseman, 1951) showed unequivocally that the L-isomers of many amino-acids disappeared from the lumen of rat small intestine faster than the corresponding Disomers. A similar phenomenon has also been shown in several species, including the dog, the chicken, and man (Clarke, Gibson, Smyth and Wiseman, 1951; Paine, Newman and Taylor, 1959; Kuroda and Gimbel, 1954; Wang and Waisman, 1961). It was also found that the L-isomers were preferentially absorbed into the portal blood (Matthews and Smyth, 1952; 1954) which showed that the results of Gibson and Wiseman (1951) could not be accounted for by bacterial destruction of L-amino acids within the lumen of the gut, or by their preferential metabolism within the gut wall. The demonstration of stereochemical specificity in absorption strongly suggested the existence of a special absorptive mechanism. Evidence that the mechanism involved active transport was presented by Wiseman (1951), who showed that L-amino acids were transported against a concentration gradient by rat small intestine in vitro. The L-isomers of most of the common monoaminomonocarboxylic amino-acids and of several dibasic amino-acids have now been shown to be actively transported (e.g., Wiseman, 1953; 1956; Wilson and Wiseman, 1954; Smyth and Whaler, 1953; Agar, Hird, and Sidhu, 1953; Neil, 1959; Spencer and Samiy, 1960; Wilson, 1962; Wiseman, 1964). Additional evidence for the existence of special mechanisms in amino-acid absorption is discussed later.

STRUCTURAL REQUIREMENTS FOR INTESTINAL TRANSPORT A considerable amount of information has now been gained about the molecular structural features influencing amino-acid transport by the small intestine. These features probably reflect some of the chemical properties of the transport mechanism or mechanisms. So far attention has been paid mainly to the requirements for active transport.

The structure of a typical amino-acid is:<smiles>[R]C(N)C(=O)O</smiles>

A carboxyl group is attached to a carbon atom, designated the $\alpha$-carbon. To this $\alpha$-carbon atom are attached a hydrogen atom, an amino group, and a side chain, ' $R$ '. This side-chain takes various forms, which distinguish the individual amino-acids. It may be a simple aliphatic chain, straight or branched (e.g., alanine, valine, leucine), it may contain sulphur atoms (e.g.., methionine, cysteine), or it may include an aromatic or heterocyclic ring (e.g., phenylalanine, tyrosine, histidine, tryptophan). It may include a second carboxyl group, forming a dicarboxylic amino-acid (e.g., glutamic acid, aspartic acid) or a second amino group, forming a dibasic (diamino) amino-acid (e.g., lysine, arginine, ornithine). All amino-acids which have four different groups around the $\alpha$-carbon can occur in L- or D-forms according to the disposition of the groups, these stereoisomers being mirror images of each other, and similar in most physical and chemical properties. The L-isomers are sometimes known as the 'natural' isomers since they are the only forms commonly met with in foodstuffs and in the tissues of higher animals. In amino-acids in which there are only three different groups 
attached to the $\alpha$-carbon, these optical isomers cannot occur; thus glycine, in which $R$ is represented by a second hydrogen atom, has only one form.

The following structural features are important in active transport (e.g., Wiseman, 1955; 1956; Wilson, Lin, Landau, and Jorgensen, 1960; Christensen, 1960; Spencer, Bow, and Markulis, 1962; Lin, Hagihira, and Wilson, 1962; Wiseman, 1964).

The amino group This is essential for active transport. Thus, acetic acid, which may be regarded as glycine in which the amino group has been replaced by a hydrogen atom, is not actively transported. Replacement of one of the hydrogen atoms of the $\alpha$-amino group, as in proline and $\mathrm{N}$-methylglycine, does not necessarily prevent active transport, though it may do so if the substituting group is bulky, as in $\mathrm{N}$-phenylglycine. If both hydrogen atoms are substituted, as in N-dimethylglycine, active transport is abolished. It also appears to be essential for the amino-group to be attached to the $\alpha$-carbon atom; if not, as in $\beta$-alanine, active transport will not take place.

The carboxyl group The carboxyl group also appears to be essential, and it must be free; thus the methyl ester of L-histidine is not actively transported.

The hydrogen of the $\alpha$-carbon This is not essential, since the amino-acids $\alpha$-aminoisobutyric acid, isovaline, and cycloleucine (which are apparently not metabolized and in which the $\alpha$-hydrogen is replaced by a methyl or other group, are actively transported, but there is evidence that the substitution reduces affinity for the transport mechanism (Christensen, 1962).

Stereochemical configuration at the $\alpha$-carbon Until recently, it was thought the L-configuration was an absolute requirement for active transport, but the finding (Jervis and Smyth, 1960) that D-methionine is transported against a concentration gradient suggests that this is not a universal rule. Evidence from experiments on competition for transport and on the kinetics of the transport process also indicates that the absorption of $D$ amino-acids, though it may be passive in many cases, is unlikely to be by simple diffiusion.

The side-chain The nature of the side-chain may also determine whether or not an amino-acid is actively transported. In the case of the monoaminomonocarboxylic amino-acids, the length of the side-chain appears to have an important influence on affinity for the transport mechanism. For some time it was thought that only the monoaminomonocarboxylic amino-acids were actively transported, but it has since been shown that the diamino acids, lysine, ornithine, and arginine, are also transported actively. There is no evidence for active transport of the dicarboxylic acids, glutamic and aspartic, though possibly such evidence is masked by extensive metabolism of these compounds in the intestinal wall.

COMPETITION FOR INTESTINAL TRANSPORT If two compounds compete for transport, this suggests that they share at least one stage in the transport process. The first systematic study of competition for absorption between amino-acids was that of Wiseman (1955). He found that diamino and dicarboxylic amino-acids had no effect on the transport of several monoaminomonocarboxylic amino-acids. Among the monoaminomonocarboxylic amino-acids, those transported at a slow rate were particularly effective in inhibiting the transport of those transported at a faster rate. Thus methionine, which is relatively slowly transported at a concentration of $20 \mathrm{mM}$, almost completely prevented transport of proline, glycine, and histidine, whereas glycine, which is relatively rapidly transported at this concentration, had little or no inhibiting effect on transport of the more slowly transported histidine and methionine. As a result, he suggested that the monoaminomonocarboxylic amino-acids shared a common transport mechanism, in which the slowly transported amino-acids had a high affinity for some part of the mechanism and formed a comparatively stable union with some part of it, thus accounting for their slow transport and high inhibiting ability.

These and other observations now enable further generalizations to be made. It is probable that the L-isomers of most, if not all, monoaminomonocarboxylic amino-acids compete with each other for intestinal transport (e.g., Pinsky and Geiger, 1952; Fridhandler and Quastel, 1955; Agar, Hird and Sidhu, 1956; Finch and Hird, 1960b,. Hagihira, Ogata, Takedatsu, and Suda, 1960; Spencer and Samiy, 1961), and that those with long side-chains are the most powerful inhibitors of the transport of other amino-acids within this group. The longer the side-chain, the more powerful the inhibiting effect, i.e., the greater the apparent affinity for the common transport mechanism (Finch and Hird, 1960b; Nathans, Tapley, and Ross, 1960; Matthews and Laster, 1965b). It also appears that there are several intestinal transport mechanisms for different groups of amino-acids, there being competition among the members of each group, but not between the members of different groups:-

1 The mechanism shared by the majority of monoaminomonocarboxylic amino-acids; 2, a mechanism for the transport of the three basic amino-acids, ornithine, lysine, arginine, and cystine (Hagihira, Lin, Samiy, and Wilson, 1961); 3, a mechanism for the transport of N-substituted amino- 
acids (betaine, dimethylglycine, and sarcosine). Two other $\mathrm{N}$-substituted amino-acids, proline and hydroxyproline, appear to be transported partly by this system and partly by that for the monoaminomonocarboxylic acids (Wilson, 1962; Hagihira, Wilson and Lin, 1962). 4 Possibly a special mechanism for the transport of glycine: this is suggested by the work of Christensen (1962) and Akedo and Christensen (1962), and Newey and Smyth (1963) have shown that glycine is probably transported partly by a special mechanism of its own and partly by that for the other monoaminomonocarboxylic amino-acids. All these experiments, however, were carried out with rat gut. In the hamster, we could find no evidence that glycine was not transported entirely by mechanism (1), so that there may be species differences in the transport of this amino-acid (Matthews and Laster, 1965b).

The results of animal experiments and of investigation of amino-acidurias in man suggest that there are similar groups of transport mechanisms in the kidney, and that certain defects in the renal mechanisms, as in Hartnup disease and cystinuria, are accompanied by corresponding defects in the intestinal mechanisms (see Milne, 1964).

Competition for intestinal transport is not confined to L-amino acids, but apparently also occurs between some D-amino acids (Agar et al., 1956). Competition has also been observed between L-amino acids and D-amino acids (Jervis and Smyth, 1959b; Paine et al., 1959). This raises the possibility that there is at least one stage in transport which is common to both L- and D- isomers.

THE KINETICS OF INTESTINAL TRANSPORT Additional information about the mechanisms of intestinal transport can be gained by studying their kinetics.
It has already been pointed out that if a substance is absorbed by simple diffusion, its rate of absorption should be approximately proportional to its concentration within the intestinal lumen. If, on the other hand, a special mechanism (active transport or facilitated diffusion) is involved, the absorption rate will not keep pace with increasing concentration, but will approach a limiting value as the absorptive mechanism becomes saturated. Höber and Höber (1937), Lathe (1943), and Hetenyi and Winter (1952) observed that the absorption of amino-acids tended to approach a limiting rate, and in recent years the kinetics of amino-acid absorption have been investigated in more detail, by techniques both in vivo and in vitro.

If the rates of transport of amino-acids are plotted against their concentrations in the intestinal lumen or on the mucosal side of a sac preparation, curves of the type shown in Fig. 4 are usually obtained. Transport rate increases with increasing concentration until a maximal rate is attained, this rate varying according to the individual amino-acid. If the reciprocal of the transport rate at each concentration is plotted against the reciprocal of the concentration (excluding the highest concentrations), the result is a straight line (Fig. 5). Figure 5 is analogous to the Lineweaver-Burk plot of enzyme kinetics, and this linear relationship has been taken to mean that the transport process conforms to the Michaelis-Menten kinetics of enzyme reactions. Kinetics of this type, which have now been shown for a number of L-amino acids and two D-amino acids (e.g., Jervis and Smyth, 1959a; Finch and Hird, 1960b; Nathans et al., 1960; Spencer and Samiy, 1961; Lin et al., 1962; Matthews and Laster, 1965a), are to be expected if the rate-limiting step in transport is combination with or adsorption to some com-

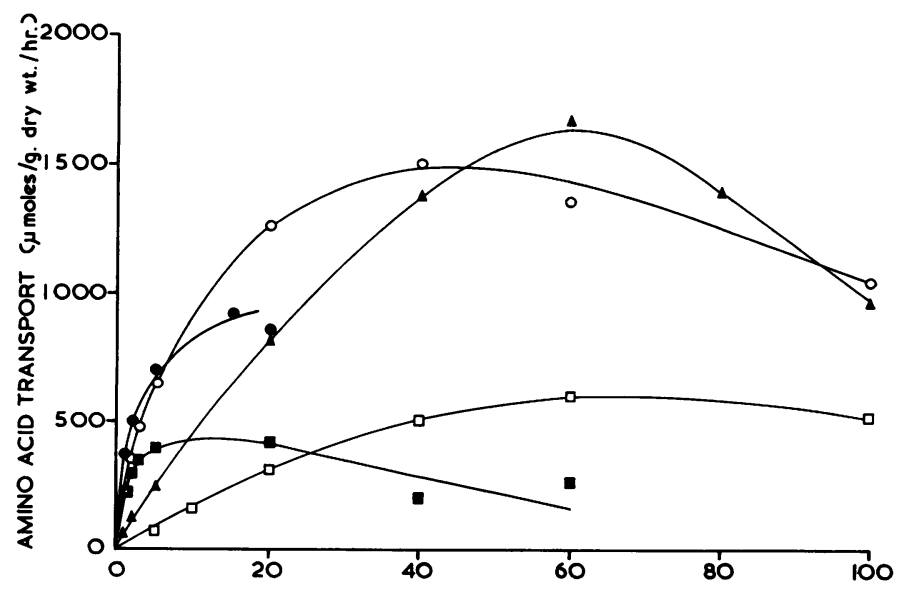

FIG. 4. The relationship between initial amino-acid concentration in the mucosal fluid and amino-acid transport into the serosal fluid, using sacs of hamster small intestine. A-glycine, o-L-alanine, $\bigcirc$-L-valine, $\square$-L-leucine, $\square \alpha$-aminoisobutyric acid. The tendency for the rates to decline at very high concentrations may be characteristic of the experimental system. (Matthews and Laster, 1965a; reproduced by permission of the Editor of the American Journal of Physiology).

INITIAL AMINO ACID CONCENTRATION (mM) 


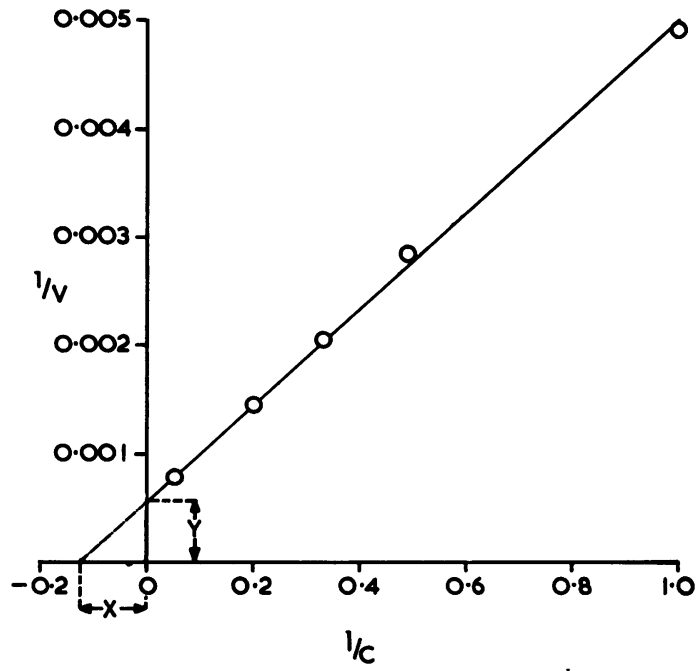

FIG. 5. Lineweaver-Burk plot for L-alanine $\frac{l}{c}=$ reciprocal of amino-acid concentration ( $m M) \frac{l}{v}=$ reciprocal of corresponding transport rate ( $\mu$ moles/g. dry wt./hr.). The data from which the plot was constructed are included in Figure 4.

ponent of the cell membrane, but it must be emphasized that such kinetics do not show that a carrier mechanism or even an enzyme system is involved in transport. The findings must in fact be interpreted with caution, because any such treatment of the data involves gross oversimplification of a complex system (Wilbrandt and Rosenberg, 1961; Wolff, 1964; Matthews and Laster, 1965a). In spite of these reservations, it is possible to derive from the Lineweaver-Burk plots two measures of transport characteristics which show a definite relationship to chemical structure (Finch and Hird, 1960b; Matthews, and Laster 1965a). The reciprocal of the distance $Y$ from the origin (Fig. 5) may be taken as indicating the apparent limiting velocity of transport in the system used $\left(\mathrm{V}_{\max }\right)$, and the reciprocal of the distance $\mathrm{X}$ as indicating the concentration at which the transport rate is half-maximal $\left(\mathrm{K}_{\mathrm{t}}\right)$. Low $\mathrm{K}_{\mathrm{t}}$ values indicate that it is relatively easy to saturate the transport mechanism with the substance transported, in other words, low $K_{t}$ values suggest high affinities for the transport mechanism, and high $\mathbf{K}_{t}$ values suggest low affinities.

Table I shows a series of monoaminomonocarboxylic amino-acids, and the corresponding $V_{\max }$ and $K_{t}$ values obtained from sac experiments. As the length of the side-chain increases, $K_{t}$ decreases, i.e., the apparent affinity for the transport mechanism becomes greater, and $V_{\max }$ also decreases. These results agree well with those of competition experiments, which show that amino-acids with long side-
TABLE I

CHEMICAL STRUCTURE AND TRANSPORT CONSTANTS FOR A SERIES OF NEUTRAL AMINO-ACIDS ${ }^{1}$

\begin{tabular}{llcc} 
Amino-acid & Side-chain & $K_{t}(m M)$. & $\begin{array}{c}V_{\max }(\mu M / g . \\
d r y w t . / h r .)\end{array}$ \\
\hline Glycine & $\mathrm{H}-$ & 43 & 2,600 \\
L-alanine & $\mathrm{CH}_{3-}$ & $7 \cdot 5$ & 1,700 \\
L-valine & $\left(\mathrm{CH}_{3}\right)_{2} \mathrm{CH}-$ & 1.9 & 960 \\
L-leucine & $\left(\mathrm{CH}_{3}\right)_{2} \mathrm{CH} . \mathrm{CH}_{2}-1 \cdot 5$ & 490
\end{tabular}

${ }^{1}$ Modified from Matthews and Laster (1965a)

chains are powerful competitive inhibitors of transport, and thus appear on these grounds to have a high affinity for the transport mechanism. Further, using the $K_{t}$ values obtained from kinetic experiments, and making certain assumptions, it is possible to calculate the expected degree of inhibition of transport of one amino-acid when it is transported in the presence of another (Finch and Hird, 1960b; Matthews and Laster. 1965b). In a limited series of monoaminomonocarboxylic amino-acids, the predicted values agree reasonably well with those actually observed in competition experiments (Table II). Lin et al. (1962) have proposed a hypothesis to explain the relationship between chemical structure and transport characteristics. They suggest that the more lipophilic the side-chain, the more readily it dissolves in the lipid-rich cell membrane, permitting the carboxyl group, amino group, and $\alpha$-hydrogen to reach the carrier or carrier site, which has attachments for these groups. This would explain the association between length of side-chain and low $K_{t}$ values. They also suggest that the reason why highly lipophilic side-chains are associated with low maximal transport rates is that they do not readily dissociate from the cell membrane, so that transport is impeded. The results so far obtained are consistent with this hypothesis.

Before leaving the subject of kinetics, it should be noted that it is possible for an amino-acid $A$ to be transported faster than an amino-acid $B$ at one

TABLE II

COMPETITIVE INHIBITION OF AMINO-ACID TRANSPORT INTO THE SEROSAL FLUID OF EVERTED SACS OF HAMSTER SMALL INTESTINE ${ }^{1}$

\begin{tabular}{|c|c|c|c|c|c|}
\hline \multirow{2}{*}{$\begin{array}{l}\text { Inhibited } \\
\text { Amino-acid } \\
\text { (concen- } \\
\text { tration } \\
20 \text { mM.) }\end{array}$} & \multirow{2}{*}{$\begin{array}{l}\text { No. of } \\
\text { Experi- } \\
\text { ments }\end{array}$} & \multirow{2}{*}{$\begin{array}{l}\text { Inhibitor } \\
\text { Amino- } \\
\text { acid }\end{array}$} & \multirow{2}{*}{$\begin{array}{l}\text { Concen- } \\
\text { tration of } \\
\text { Inhibitor } \\
\text { Amino- } \\
\text { acid }(\mathrm{mM})\end{array}$} & \multicolumn{2}{|c|}{$\begin{array}{l}\text { Percentage Inhibition } \\
\text { of Transport }\end{array}$} \\
\hline & & & & Observed & Predicted \\
\hline Glycine & $\begin{array}{l}2 \\
2 \\
3\end{array}$ & $\begin{array}{l}\text { L-alanine } \\
\text { L-alanine } \\
\text { L-leucine }\end{array}$ & $\begin{array}{r}5 \\
20 \\
2\end{array}$ & $\begin{array}{l}31 \\
86 \\
62\end{array}$ & $\begin{array}{l}31 \\
64 \\
47\end{array}$ \\
\hline L-alanine & 2 & $\begin{array}{l}\text { Glycine } \\
\text { L-leucine }\end{array}$ & $\begin{array}{r}40 \\
2\end{array}$ & $\begin{array}{l}21 \\
30\end{array}$ & 20 \\
\hline L-leucine & $\begin{array}{l}2 \\
2\end{array}$ & $\begin{array}{l}\text { Glycine } \\
\text { L-alanine }\end{array}$ & $\begin{array}{l}40 \\
40\end{array}$ & $\begin{array}{r}0 \\
27\end{array}$ & $\begin{array}{r}6 \\
28\end{array}$ \\
\hline
\end{tabular}

${ }^{1}$ Modified from Matthews and Laster (1965b) 
concentration, but more slowly at another (Fig. 4), and according to the concentration used, a series of amino-acids may show several different orders of transport rate. This may explain why in earlier investigations where amino-acid absorption was studied at one concentration only (e.g., Kratzer, 1944), no clear relationship emerged between transport rate and chemical structure. There is, however, a general tendency for amino-acids with low $K_{t}$ values to be transported relatively fast at low concentrations, and relatively slowly at high concentrations. This probably explains why Wiseman (1955), working at the comparatively high concentration of $20 \mathrm{mM}$, found a correlation between slow transport and powerful competitive ability. It is now clear that to say that a particular amino-acid is transported relatively 'fast' or 'slowly' is meaningless unless the concentration is specified.

RELATIONSHIP OF INTESTINAL TRANSPORT TO METABOLIC ENERGY SUPPLY There is little doubt that the energy for the active transport of amino-acids by the intestine of the adult animal is derived from oxidative metabolism. Transport is inhibited by anoxia and various metabolic inhibitors, including cyanide and $2: 4$ dinitrophenol (e.g., Agar et al., 1953; Wilson and Wiseman, 1954; Jervis and Smyth, 1960). There remains, however, a possibility that the mechanisms affected are not in fact directly concerned in supplying energy for transport but serve primarily to maintain the integrity of the cell membrane, without which the transport process cannot operate (Finch and Hird, 1960a; Newey and Smyth, 1962). The energy supply is probably dependent on adenosine triphosphate (A.T.P.). It has been claimed (Fehér, Kertai, and Gáti, 1956; Kertai, Feherr, and Gáti, 1956) that if resynthesis of A.T.P. is blocked by iodoacetic acid, the A.T.P. content of the intestinal wall falls during the absorption of glycine, and that when the wall is depleted of A.T.P., the rate of glycine absorption diminishes. However, these authors found that the A.T.P. content also falls during the absorption of urea, which is almost certainly not an active process. This raises some doubt about the significance of their findings. According to Shishova $(1956 ; 1959)$, the presence of A.T.P., magnesium, and phosphate in the intestinal lumen accelerates the absorption of amino-acids, though Christensen (1960) comments that an energizing action of A.T.P. added to the outside of a tissue is very unusual. Unlike the adult gut, small intestine of foetal and newborn rabbits can transport amino-acids actively under anoxic conditions, the energy apparently being supplied by anaerobic glycolysis (Wilson and Lin, 1960).
MISCELLANEOUS FACTORS INFLUENCING AMINO-ACID ABSORPTION These must be considered separately.

Pyridoxal and its derivatives; Other vitamins Owing to the suggestion that a derivative of pyridoxal might function as a carrier in the mechanism for amino-acid concentration by tissue cells (Christensen, Riggs, and Coyne, 1954), several studies have been made on the effect of this compound and other forms of vitamin $\mathbf{B}_{6}$ on amino-acid absorption. Though the addition of pyridoxal has no effect on the transport of amino-acids by hamster small intestine in vitro (Wiseman, 1957), amino-acid absorption is depressed by pyridoxal deficiency and by the antimetabolite desoxypyridoxine (Fridhandler and Quastel, 1955; Jacobs and Hillman, 1958). Inhibition of transport produced by $2: 4$ dinitrophenol is said to be reversible by pyridoxal phosphate but not by pyridoxal, and it has been suggested that the effect of D.N.P. is to interfere with the phosphorylation of pyridoxal, thus cutting off the supply of pyridoxal phosphate, which is supposed to be active in the absorptive mechanism (e.g., Jacobs, Coen, and Hillman, 1960). While there is little doubt that pyridoxal and related compounds have some influence on the absorption of amino-acids, their role in a carrier mechanism is more than doubtful and their mode of action still not clear. Perhaps pyridoxal modifies the cell membrane so as to slow the efflux of amino-acids (Christensen, 1962). The members of the $B_{6}$ group are the only vitamins which have definitely been shown to affect amino-acid absorption, though Erf and Rhoads (1940) noted that the glycine tolerance curve was depressed in pernicious anaemia but not in other severe anaemias. Any effect of $\mathrm{B}_{12}$ deficiency may well be nonspecific (Reynolds, Hallpike, Phillips and Matthews, 1965). The absorption of xylose may also be defective in pernicious anaemia (e.g., Butterworth, PerezSantiago, de Jesus, and Santini, 1959).

Electrolyte concentration The active transport of amino-acids by the small intestine is sodiumdependent, and, in the absence of this ion, is greatly reduced or abolished. This is not a specific effect, as the transport of water, glucose, and inorganic phosphate is also inhibited. Low concentrations of potassium have no effect (at least on monoiodotyrosine transport) but high concentrations are inhibitory, and the inhibition appears to be competitive. Alterations in calcium concentration have no effect (Nathans et al., 1960; Csáky, 1961; Harrison and Harrison, 1963).

Water absorption Using in vitro preparations there is a correlation between water and amino-acid transport (Matthews and Laster, 1965a) as there is between water and glucose transport (Fullerton and Parsons, 1956; Smyth and Taylor, 1957). Possibly 
the absorption of amino-acids is assisted by 'solvent drag', that is, the entrainment of solute molecules in a water stream. There are, however, several other possible explanations for this association, and the work of Newey and Smyth (1962) suggests that solvent drag is not an important factor in the absorption of amino-acids.

$\mathrm{pH}$ The optimal $p \mathrm{H}$ for transport of monoiodotyrosine by rat small intestine in vitro is about 6 (Nathans et al., 1960).

Bile Absence of bile from the intestine is said to decrease nitrogen absorption (see Wiseman, 1964). Dawson and Matthews (1961) found that the addition of conjugated bile salts to sac preparations increased the permeability of the cells of the intestinal wall to amino-acids, allowing larger quantities to pass from the interior of the cells into the surrounding medium, but there was no appreciable effect on amino-acid transport from mucosal to serosal fluids. On the other hand, Parkinson and Olson (1963) found that transport was reduced, and suggested that bile salts might 'regulate' the absorption of various nutrients. Unconjugated bile salts abolish the active transport of amino-acids and glucose, and damage the intestinal mucosa (Dawson and Isselbacher, 1960).

Diet Kershaw, Neame, and Wiseman (1960) found that if rats were given a restricted diet for a few days there was a striking increase in the rates of absorption of L-histidine and of glucose, both in vivo and in vitro, in spite of the fact that the small intestine became shorter, narrower, and thinnerwalled. The increased absorptive ability disappeared after several days on a normal diet. A similar increase in absorption rate was found in sarcomabearing rats (Wiseman, Neame, and Ghadially, 1959). The mechanisms of these adaptations are unknown. Lin and Wilson (1960) gave rats additional tyrosine for a month, but found no change in its absorption rate.

Monosaccharide absorption There are conflicting reports about the effects of monosaccharides on amino-acid absorption. Cori (1926) reported that high concentrations of glucose in the intestine inhibited the absorption of amino-acids, an effect which Fridhandler and Quastel (1955) felt was probably osmotic. Agar et al. (1953) stated that glucose and amino-acids did not compete for absorption. More recently Newey and Smyth (1964) reported that in sac preparations glycine transport is stimulated by glucose but inhibited by galactose, and consider that this may be due to alterations in the amounts of A.T.P. available for supplying energy for amino-acid transport.

Drugs Little is known about the effects of drugs on amino-acid absorption. Phlorrhizin, which inhibits the absorption of glucose, probably by interfering with its entry into the mucosal cells, has no effect on the absorption of amino-acids (Fridhandler and Quastel, 1955; Parsons, Smyth, and Taylor, 1958). Chlortetracycline in the intestinal lumen inhibits the absorption of L-histidine (Agar and Parker, 1958); the authors suggest that this is due to interference with energy supply owing to depression of mitochondrial phosphorylation. Draper (1958) claimed that oral penicillin increased the absorption of lysine. The effect of anaesthesia on amino-acid absorption does not seem to have been studied.

Species differences Most of the recent work on amino-acid absorption has been carried out with intestine from the rat or golden hamster, but observations have also been made in the frog, chick, rabbit, cat, dog, guinea-pig, and in man. No major differences in the absorptive mechanisms have yet been observed, though the possibility of minor differences has already been referred to. Lin and Wilson (1960) compared the absorption rates of L-tyrosine in the chick, hamster, rabbit, and rat: the rates decreased in that order.

Other possible influences on amino-acid absorption Many factors that may influence the absorption of amino-acids have not yet been investigated. There is very little information about the effects of alterations in intestinal motility or in blood flow, though Cummins and Almy (1953) reported that drug-induced hypermotility accelerated methionine absorption. Nothing is known about the effects of hormones, nor about the effects of age or sex. (Sex differences are believed to exist in the rate of absorption of glucose.)

METABOLIC CHANGES DURING ABSORPTION Numerous metabolic changes have been shown to occur during the intestinal transport of amino-acids, but there is no positive evidence that they are related to the transport mechanisms, and they are, with a few exceptions, quantitatively unimportant (Wiseman, 1953; Whaler, 1955; Finch and Hird, 1960a; Wiseman, 1964). The possible metabolic pathways available to amino-acids in the intestinal wall are summarized by Spencer and Knox (1960).

Substantial amounts of L-glutamic and Laspartic acids are transaminated during absorption (Matthews and Wiseman, 1953; Neame and Wiseman, 1957 ; 1958) which results in the appearance of alanine in the portal blood, in addition to the amino-acid present in the intestinal lumen. When the lumen concentration of glutamic acid is low, it is all transaminated, and only alanine appears in the blood. Many metabolic pathways are apparently available to glutamine and glutamic acid in the 
intestinal wall (Spencer and Knox, 1960; Spencer and Zamcheck, 1961) and it is potentially able to interconvert these compounds, but there is no evidence that such interconversion occurs during absorption, at least in the cat and guinea-pig (Bessman, Magnes, Schwerin, and Waelsch, 1948; Fridhandler and Quastel, 1955). In contrast to glutamine, asparagine is almost completely hydrolysed to aspartic acid and ammonia during transport by guinea-pig intestine (Fridhandler and Quastel, 1955). Sugawa, Akedo, and Suda (1960) report that methionine sulphoxide is formed during the absorption of methionine by the rat, and partly reduced again to methionine in the portal blood.

The small intestine, which is constantly producing fresh epithelial cells, enzymes, and mucus, is an extremely active site of protein synthesis (Block, 1946; Friedberg, Tarver, and Greenberg, 1948; Busch, Davis, Honig, Anderson, Nair, and Nyhan, 1959) and it is quite possible that small amounts of amino-acids are diverted to protein synthesis during the process of absorption. Labelled amino acids given orally appear very rapidly in the protein coating of chylomicrons, which suggests that this may be synthesized in the intestinal wall (Bragden, 1958).

THE SITE AND ROUTE OF ABSORPTION Many references to early work on the site of absorption of protein digestion products are given by Verzár and McDougall (1936). The more recent observations, which have mostly been made on sacs of small intestine from the rat or hamster, show that the site of maximum ability to transport monoaminomonocarboxylic amino-acids against a concentration gradient is in the ileum, in the mid to lower part of the small intestine (e.g., Wilson and Wiseman, 1954; Lin and Wilson, 1960; Spencer and Samiy, 1960; 1961; Nathans et al., 1960; Christensen, 1962; Matthews and Laster, 1965a). These findings are in contrast to those for monosaccharides, which are best transported in the duodenum (see Crane, 1960). L-cystine and L-cysteine may be unusual in being best transported in the duodenum and jejunum (Neil, 1959). There is probably no active transport mechanism for amino-acids in the colon (Cordero and Wilson, 1961).

It is not yet clear what determines the site of maximal absorptive capacity for a particular substance. The findings quoted cannot be explained merely as a function of mucosal surface area, or of the rate of aerobic metabolism, both of which are greatest in the upper small intestine. It should be emphasized here that the site of maximum absorptive ability as determined in vitro is not necessarily identical with the site in which most absorption takes place in vivo (Crampton and Matthews, 1964). It is at least possible that with a substance which is very readily absorbed, absorption may be virtually complete before the lower part of the small intestine is reached.

Having left the cells of the mucosal epithelium, amino-acids pass across the subepithelial space into the capillaries of the villi, presumably by diffusion. While there is no doubt that the main route of absorption is into the blood, absorption into the lymph is not necessarily entirely negligible (Hendrix and Sweet, 1917; Bolton and Wright, 1937). It is assumed that absorption into the blood predominates because the rate of blood flow is far greater than that of the lymph (see Wiseman, 1964) and because of the peripheral position of the capillaries of the villi as opposed to the central position of the lacteals.

\section{THE ABSORPTION OF PEPTIDES}

There has never been any satisfactory evidence that peptides are absorbed into the blood in appreciable quantities. The older claims that large amounts of peptides appear in the blood after a protein meal (e.g., London and Kotschneff, 1934) may be discounted on the grounds of inadequate analytical technique (Christensen and Lynch, 1946; Christensen, Decker, Lynch, MacKenzie, and Powers, 1947), and more recent investigations have shown that there is no significant increase in blood peptides or amino-acid conjugates after protein feeding (Dent and Schilling, 1949; Parshin and Rubel 1951; Christensen et al., 1947; Stein and Moore, 1954). However, the advent of in vitro methods has thrown new light on the question of the absorption of peptides and revealed some unexpected facts.

When the transport of di- and tripeptides was investigated using isolated small intestine, it was found that (with the exception of small quantities of glycylglycine) they were unable to cross the intestinal wall intact; they were hydrolysed by the preparation, and only their constituent amino-acids appeared on the serosal side of the gut (Agar et al., 1954; Johnston and Wiggans, 1958; Wiggans and Johnston, 1959). Newey and Smyth $(1959 ; 1960)$ investigated the question of whether the failure of small peptides to cross the intestinal wall was due to hydrolysis in the fluids surrounding the gut, or to hydrolysis within the intestinal wall. Using both in vitro and in vivo methods, they showed that extracellular peptidases were capable of hydrolysing only a small fraction of the peptides disappearing from the mucosal side of the intestine; this meant that the peptides must be hydrolysed either at the surface of the mucosal cells, or within them. Further experimental evidence indicated that most of the 
hydrolysis was intracellular. Subsequent work (Newey and Smyth, 1962), carried out mainly with glycylglycine, suggests that dipeptides enter the cells of the intestinal mucosa partly by diffusion, but not entirely so, since the rate of entry of glycylglycine is approximately the same as that of glycine, and entry is reduced by anoxia. They are hydrolysed within the cells, and the amino-acids formed attach themselves to a transport mechanism within the cells (though there is some diffusion back into the intestinal lumen). This transport mechanism, which Newey and Smyth term the 'exit' mechanism, may be shared by free amino-acids which have entered from the lumen of the intestine.

This work shows that in addition to the absorption of free amino-acids, there is probably a second mode of absorption of protein digestion products, in which small peptides enter the mucosal cells, are hydrolysed within them, and pass into the blood stream as amino-acids. The proportions of ingested protein which leave the intestinal lumen in the form of free amino-acids and in the form of peptides are not yet known. It is interesting that these recent investigations show that there was some truth in the old view (Starling, 1906) that the final hydrolysis of foodstuffs might occur during the actual process of absorption.

THE ABSORPTION OF WHOLE PROTEINS

In the first few days or weeks of life, animals of several species can absorb a variety of proteins apparently unchanged, and substantial amounts of colostrum proteins, including maternal antibodies, are absorbed in this way (e.g., Howe, 1921; Smith, 1948; McCance, Hutchinson, Dean, and Jones, 1949; Hill and Hardy, 1956; Clark, 1959; McCance and Widdowson, 1959). The process is selective, for foreign proteins are absorbed less well than maternal antibodies, and interfere with their absorption (Brambell, Halliday, and Morris, 1958). During the absorption of whole protein, it appears in vacuoles within the columnar cells of the intestinal mucosa. These are formed by invagination of the apical cell membrane, i.e., absorption is by pinocytosis. The ingestion of materials in this way is characteristic of certain cells in primitive organisms, and its persistence in the gut of the newborn animal probably serves a nutritive function while the digestive mechanisms are still relatively undeveloped (Hill, 1956). In experimental animals, the ability to absorb whole protein is lost after the first two to three weeks, and this can be hastened by giving cortisone (Halliday, 1958; Clark, 1959). In rats and mice, the site of absorption of whole proteins is the jejunum and ileum, but not the duodenum (Clark, 1959); the route of absorption is via the lymphatics and not into the blood (Comline, Roberts, and Titchen, 1951). Comparatively little is known about the absorption of whole proteins in the human neonate, but there is no evidence for substantial absorption of maternal antibodies (Kekwick, 1959). Babies can be shown to absorb small amounts of intact cow's milk, egg, and other foreign proteins by immunological techniques (e.g., Wilson and Walzer, 1935; Gruskay and Cooke, 1955) but this does not indicate that whole proteins are absorbed in nutritionally significant amounts.

It is very unlikely that adult animals can absorb intact foreign proteins except in minute quantities. Rats can be sensitized to foreign proteins given orally (Ratner and Gruehl, 1934), and after giving egg albumin to dogs, it is detectable by a precipitin reaction in the lymph, though not in the portal blood (Alexander, Shirley, and Allen, 1936). Allergic reactions to a variety of food proteins are not uncommon in man, and are evidence of absorption of protein either unchanged or only slightly modified; such absorption can also be shown immunologically (e.g., Sussman, Davidson, and Walzer, 1928). In all these examples, absorption is on a very small scale. Under certain conditions, insulin is absorbed from intestinal loops in dogs (Murlin, Tomboulian, and Pierce, 1937); it is also absorbed by rats if proteolysis is artificially inhibited, and can cross the walls of intestinal sacs (Danforth and Moore, 1959), but in these experiments the normal digestive processes are prevented.

The literature contains several reports suggesting that plasma proteins from an animal itself or from another of the same species may be absorbed in large quantities either intact or at any rate without extensive hydrolysis (Voit and Bauer, 1869; Heidenhain, 1894; Visscher, Roepke, and Lifson, 1945; Dent and Schilling, 1949). Dent and Schilling fed homologous plasma to dogs, and it appeared to be absorbed without significant alteration in the aminoacids or small peptides of the portal blood. This could mean that either it was absorbed intact, or in the form of peptides too large to be detected by the paper chromatographic methods used. Subsequent work, however, suggests that homologous plasma proteins are completely hydrolysed during absorption (Abdou and Tarver, 1951; Yuile, O'Dea, Lucas, and Whipple, 1952).

\section{HYPOTHESES OF THE MECHANISMS OF ABSORPTION OF AMINO-ACIDS AND PEPTIDES}

It appears from work with small intestine in vitro that concentrative uptake of amino-acids by the 
cells of the intestinal mucosa is an essential part of the process of active transport across the intestinal wall (Agar et al., 1956; Finch and Hird, 1960a; Newey and Smyth, 1962). For this reason, and because there are many resemblances between intestinal transport of amino-acids and their transport into tissue cells, Christensen $(1960 ; 1962)$ has proposed that the intestinal transport mechanism is essentially a modification of the ordinary cell concentration mechanism. If transport into the mucosal cells were more vigorous on the mucosal side than on the other, transport across the cells would take place. Christensen and Oxender (1960) have shown experimentally that this is possible, by forming Ehrlich ascites carcinoma cells into a thin membrane on a fine filter. If uptake is stimulated on one side of this membrane (by adding pyridoxal or establishing a potassium gradient) amino-acids are transported against a concentration gradient from one side to the other. In the intestine, it is possible that more vigorous transport on the luminal border of the mucosal cells might be produced by an extra number of transport sites on this side, perhaps situated in the brush border.

The work of Newey and Smyth suggests that transport across the mucosal epithelium is more complicated than this (Smyth, 1961a; Newey and Smyth, 1962). They propose that there are two stages in the transport of glycine: (1) an entry mechanism, where competition with methionine occurs, and (2) an exit mechanism, which is relatively uninfluenced by methionine competition, but does require aerobic energy. This exit mechanism is probably shared by amino-acids which have been liberated within the cells by hydrolysis of peptides.

The nature of the mechanisms responsible for amino-acid transport across cell membranes is unknown. Certain chemical reactions which might possibly be concerned in amino-acid transport into tissue cells have been ruled out by the observation that there is no exchange of carboxyl oxygen during the transport process (Christensen, Parker, and Riggs, 1958). The glucuronide formation that has been reported during the intestinal transport of monoiodotyrosine (Tapley, Herz, Ross, Deuel, and Leventer, 1960) and the formation of methionine sulphoxide during the absorption of methionine (Sugawa et al., 1960) may well be incidental rather than reactions concerned in the transport mechanism. The hypothesis of the 'shuttling carrier' has already been touched on. For a time it appeared that the carrier involved in amino-acid transport might be pyridoxal or some related compound, but this now seems unlikely. Christensen (1962) points out that in spite of the usefulness of the carrier concept, no example of a carrier has yet been identified either in the intestine or elsewhere; he discusses other possible explanations of carrier-like behaviour in membrane transport. The terms 'carrier' and 'carrier site' now tend to be used merely to refer to hypothetical reactive sites concerned with transport, without committing the user to the shuttling carrier concept.

Certain characteristics of the 'carrier sites' involved in intestinal transport of amino-acids are indicated by the structural requirements for transport, and these have been outlined. The fact that different groups of amino-acids appear to be transported by separate mechanisms suggest that there are several categories of transport site with different chemical specificities.

The details of how the metabolic energy supply is linked to the transport mechanism or mechanisms are unknown. Christensen et al. (1954) suggested that in tissue cells, amino-acid transport might be linked with, and perhaps driven by, potassium transport. A raised potassium concentration acts like a competitive inhibitor of amino-acid transport (Nathans et al., 1960) which suggests that the two transports are also associated in some way in the intestine. The abolition of the transport of both glucose and amino-acids by low sodium concentrations may be the result of interference with a common energy supply to the two mechanisms. Crane (1960) proposed that the active transport of sugars by the intestine might be driven by the extrusion of sodium from the base of the microvilli, leading to an inflow of water carrying solutes with it, the entry of solutes being controlled by the chemical specificities of special entry sites. Possibly a similar mechanism might be invoked to account for the active transport of amino-acids.

Though there have been many advances in the last 15 years, it is not yet possible to form a complete picture of the intestinal absorption of protein breakdown products, and one of the central problems, the nature of the transport mechanisms for amino-acids, is still unsolved. Much remains to be learnt, and recent physiological findings have only just begun to be applied in clinical investigation. The field continues to offer great opportunities.

\section{REFERENCES}

Abderhalden, E. (1912) Synthese der Zellbausteine. Springer, Berlin.

—, Körösy, K V., and London, E. S. (1907) Weitere Studien über die normale Verdauúng der Eiweisskörper im Magendarmkanal des Hundes. Hoppe-Sevlers Z. physiol. Chem., 53, 148-163.

Abdou, I. A., and Tarver, H. (1951). Plasma protein. I. Loss from circulation and catabolism to carbon dixoide. J. biol. Chem., 190, 769.780

Abel, J. J., Rowntree, L. G., and Turner B. B. (1914). On the removal of diffusible substances from the circulating blood of living animals by dialysis. J. Pharmacol. exp. Ther., 5, 275-316. 
Agar, W. T., Hird, F. J. R., and Sidhu, G. S. (1953). The active absorption of amino-acids by the intestine. J. Physiol. (Lond.), 121, 255-263.

$-,-1954)$. The uptake of amino-acids by the intestine. Biochim. biophys. Acta (Amst.), 14, 80-84. amino-acids by intestinal tissue. Ibid., 22, 21-30.

- and Parker, M. A. (1958). The inhibition of the intestinal absorption of an amino-acid by chlortetracycline. Ibid., 30, 243-246.

Akedo, H., and Christensen, H. N. (1962). Transfer of amino-acids across the intestine: a new model amino-acid. J. biol. Chem., 237, 113-117.

Alexander, H. L., Shirley, K., and Allen, D. (1936). The route of ingested egg white to the systemic circulation. J. clin. Invest., 15, 163-167.

Andrews, J. C., Johnston, C. G., and Andrews, K. C. (1936). The absorption of cystine, methionine, and cysteic acid from intestinal loops of dogs. Amer. J. Physiol., 115, 188-193.

Berliner, R. W. (1959). Membrane transport. Rev. mod. Phys., 31, 342-348.

Bessman, S. P., Magnes, J., Schwerin, P., and Waelsch, H. (1948). The absorption of glutamic acid and glutamine. J. biol. Chem. 175, 817-823.

Block, K. (1946). The metabolism of $1(+)$-arginine in the rat. Ibid., 165, 469-476.

Bolton, C., and Wright, G. P. (1937). The absorption of amino-acids and their distribution in the body fluids. J. Physiol. (Lond.), 89, 269-286.

Booth, C. C., and Kanaghinis, T. (1963). A dual mechanism of absorption of L-tryptophan. Ibid., 167, 18P.

Bragden, J. H. (1958). On the composition of chyle chylomicrons. J. Lab. clin. Med., 52, 564-570.

Brambell, F. W. R., Halliday, R., and Morris, I. G. (1958). Interference by human and bovine serum and serum protein fractions with the absorption of antibodies by suckling rats and mice. Proc. roy. Soc., B, 149, 1-11.

Buglia, G. (1912). Untersuchungen über die biologische Bedeutung und den Metabolismus der Eiweisstoffe. X. Gesamtstickstoff und Aminosäurestickstoffe im Harn der per os mit Fleisch oder auf intravenösem Wege mit den Verdauungsbrodukten des Fleisches ernährten Tiere. $Z$. Biol., 58, 162-184.

Butterworth, C. E., Jr., Perez-Santiago, E., Martinez de Jesus, J., and Santini, R. (1959). Studies on the oral and parenteral administration of $\mathrm{D}(+)$-xylose. New Engl. J. Med., 261, 157-164.

Busch, H., Davis, J. R., Honig, G. R., Anderson, D. C., Nair, P. V., and Nyhan, W. L. (1959). The uptake of a variety of aminoacids into nuclear proteins of tumors and other tissues. Cancer Res., 19, 1030-1039.

Cathcart, E. P., and Leathes, J. B. (1906). On the absorption of proteids from the intestine. J. Physiol. (Lond.), 33, 462-475.

Chase, B. W., and Lewis, H. B. (1934). Comparative studies of the metabolism of amino acids. VI. The rate of absorption of leucine, valine, and their isomers from the gastrointestinal tract of the white rat. J. biol. Chem., 106, 315-321.

Christensen, H. N. (1960). Reactive sites and biological transport. Advanc. Protein., Chem., 15, 239-314.

(1962). Intestinal absorption with special reference to aminoacids. Fed. Proc., 21, 37-42.

- , Decker, D. G., Lynch, E. L., MacKenzie, T. M., and Powers, J. H. (1947). The conjugated, non-protein, amino-acids of plasma. V. A study of the clinical significance of peptidemia. J. clin. Invest., 26, 853-859.

_- and Lynch, E. L. (1946). The conjugated, non-protein, aminoacids of plasma. I. Postabsorptive concentrations of human plasma, serum, and erythrocytes. J. biol. Chem., 163, 741-751. and Oxender, D. L. (1960). Transport of amino acids into and across cells. Amer. J. clin. Nutr., 8, 131-136.

, Parker, H. M., and Riggs, T. R. (1958). Nonexchange of carboxyl oxygen in mammalian amino acid transport. $J$. biol. Chem., 233, 1485-1487.

-, Riggs, T. R., and Coyne, B. A. (1954). Effects of pyridoxal and indoleacetate on cell uptake of amino acids and potassium. lbid., 209, 413-427.

Clark, S. L., Jr. (1959). The ingestion of proteins and colloidal materials by columnar absorptive cells of the small intestine in suckling rats and mice. J. biophys. biochem. Cytol., 5, 41-49.

Clarke, E. W., Gibson, Q. H., Smyth, D. H., and Wiseman, G. (1951). Selective absorption of amino-acids from Thiry-Vella loops. J. Physiol. (Lond.), 112. 46P.
Cohnheim, O. (1901). Die Umwandlung des Eiweiss durch die Darmwand. Zeit. physiol. Chem., 33, 451-465.

Comline, R. S., Roberts, H. E., and Titchen, D. A. (1951). Histological changes in the epithelium of the small intestine during protein absorption in the new-born animal. Nature (Lond.), 168, 84-85.

Cordero N., and Wilson, T. H. (1961). Comparison of transport capacity of small and large intestine. Gastroenterology, 41, 500-504.

Cori, C. F. (1926). The absorption of glycine and d, l-alanine. Proc. Soc. exp. Biol. (N.Y.), 24, 125-126.

Crampton, R. F. and Matthews, D. M. (1964). Kinetics of drug absorption: methods and interpretation. In Absorption and Distribution of Drugs, pp. 49-63 Ed. Binn's. T. B. Livingstone, Edinburgh and London.

Crane, C. W. (1961). Some aspects of protein digestion and absorption in health and disease. Postgrad. med. J., 37, 745-754.

, and Neuberger, A. (1960). The digestion and absorption of protein by normal man. Biochem. J., 74, 313-323.

Crane, R. K. (1960). Intestinal absorption of sugars. Physiol. Rev., 40, 789-825.

- , and Mandelstam, P. (1960). The active transport of sugars by various preparations of hamster intestine. Biochim. biophys. Acta (Amst.), 45, 460-476.

and Wilson, T. H. (1958). In vitro method for the study of the rate of intestinal absorption of sugars. J. appl. Physiol., 12, $145-146$.

Csáky, T. Z. (1961). Significance of sodium ions in active intestinal transport of nonelectrolytes. Amer J. Physiol., 210, 999-1001.

Cummins, A. J., and Almy, T. P. (1953). Studies on the relationship between motility and absorption in the human small intestine. Gastroenterology, 23, 179-190.

Danforth, E., Jr., and Moore, R. O. (1959). Intestinal absorption of insulin in the rat. Endocrinology, 65, 118-123.

Darlington, W. A., and Quastel, J. H. (1953). Absorption of sugars from isolated surviving intestine. Arch. Biochem., 43, 194-207.

Dawson, A. M., and Isselbacher, K. J. (1960). Studies on lipid metabolism in the small intestine with observations on the role of bile salts. J. clin. Invest., 39, 730-740.

amino-acid production by small intestinal in vitro. J. Physiol. (Lond.), 159, 57-58P.

Draper, H. H. (1958). The absorption of radiolysine by the chick as affected by penicillin administration. J. Nutr., 64, 33-42.

Dent, C. E., and Schilling, J. A. (1949). Studies on the absorption of proteins: the amino-acid pattern in the portal blood. (Addendum. Christensen, H. N., Conjugated amino-acids in portal plasma of dogs after protein feeding.) Biochem. J., 44, 318-335.

Denton, A. E., and Elvehjem, C. A. (1954). Availability of amino acids in vivo. J. biol. Chem., 206, 449-454.

_ Gershoff, S. N., and Elvehjem, C. A. (1953). A new method for cannulating the portal vein of dogs. Ibid., 204, 731-735.

Elsden, S. R., Gibson, Q. H., and Wiseman, G. (1950). Selective absorption of amino-acids from the small intestine of the rat. J. Physiol., III, 56P.

Erf, L. A., and Rhoads, C. P. (1940). The glycine tolerance test in sprue and pernicious anemia. J. clin. Invest., 19, 409-421.

Feher, I., Kertai, P., and Gáti, T. (1956). The role of the ATP content of the intestinal muocsa in the absorption of glucose. Acta physiol. Acad. Sci. hung., 10, 19-32.

Finch, L. R., and Hird, F. J. R. (1960a). The uptake of amino acids by isolated segments of rat intestine. I. A survey of factors affecting the measurement of uptake. Biochim. biophys. Acta (Amst.), 43, 268-277.

- $1960 \mathrm{~b})$. The uptake of amino acids by isolated segments of rat intestine. II. A survey of affinity for uptake from rates of uptake and competition for uptake. Ibid., 43, 278-287.

Fisher, R. B. (1954). Protein Metabolism. Methuen. London.

- , and Parsons, D. S. (1949). A preparation of surviving rat small intestine for the study of absorption. J. Physiol. (Lond.), 110, 36-46.

Folin, O., and Denis, W. (1912). Protein metabolism from the standpoint of blood and tissue analysis. J. biol. Chem., 11, 87-95.

Fridhandler, L., and Quastel, J. H. (1955). Absorption of amino acids from isolated surviving intestine. Arch. Biochem. 56, 424-440.

Friedberg, F., Tarver, H., and Greenberg, D. M. (1948). The distribution pattern of sulfur-labeled methionine in the protein and the free amino acid fraction of tissues after intravenous administration. J. biol. Chem., 173, 355-361. 
Fullerton, P. M., and Parsons, D. S. (1956). Absorption of sugars and water from rat intestine in vivo. Quart. J. exp. Physiol., 41, 387-397.

Gibson, Q. H., and Wiseman, G. (1951). Selective absorption of stereo-isomers of amino acids from loops of the small intestine of the rat. Biochem. J., 48, 426-429.

Gruskay, F. L., and Cooke, R. E. (1955). The gastrointestinal absorption of unaltered protein in normal infants and in infants recovering from diarrhea. Pediatrics, 16, 763-769.

Hagihira, H., Ogata, M., Takedatsu, N., and Suda, M. (1960). Intestinal absorption of amino acids. III. Interference between amino acids during intestinal absorption. J. Biochem. (Tokyo), 47, 139-143.

_-, Lin, E. C. C., Samiy, A. H., and Wilson, T. H. (1961). Active transport of lysine, ornithine, arginine and cystine by the intestine. Biochem. biophys. Res. Commun., 4, 478-481.

-, Wilson, T. H., and Lin, E. C. C. (1962). Intestinal transport of certain N-substituted amino acids. Amer. J. Physiol., 203, 637-640.

Halliday, R. (1958). The increase in alkaline phosphatase activity of the duodenum and decrease in absorption of antibodies by the gut induced in young rats by desoxycorticosterone acetate. J. Physiol. (Lond.), 140, 44-45P.

Harrison, H. E., and Harrison, H. C. (1963). Sodium, potassium, and intestinal transport of glucose, l-tyrosine, phosphate, and calcium. Amer. J. Physiol., 205, 107-111.

Heidenhain, R. (1894), Neue Versuche über die Aufsaugung Dündarm. Pflügers Arch. ges. Physiol., 56, 579-631.

Henderson, Y, and Dean, A. L. (1903). On the question of proteid synthesis in the animal body. Amer. J. Physiol., 9, 386-390.

Hendrix, B. M., and Sweet, J. E. (1917). A study of amino nitrogen and glucose in lymph and blood before and after the injection of nutrient solutions in the intestine. J. biol. Chem., 32, 299-307.

Hetenyi, G., Jr., and Winter, M. (1952). Contribution to the mechanism of the intestinal absorption of amino acids. Acta. physiol. Acad. Sci., hung., 3, 49-58.

Hill, K. J. (1956). Gastric development and antibody transference in the lamb, with some observations on the rat and guinea-pig. Quart. J. exp. Physiol., 41, 421-432.

- and Hardy, W. S. (1956). Histological and histochemical observations on the intestinal cells of lambs and kids absorbing colostrum. Nature (Lond.), 178, 1353-1354.

Höber, R., and Höber, J. (1937). Experiments on the absorption of organic solutes in the small intestine of rats. J. cell. comp. Physiol., 10, 401-422.

Horváth, I., and Wix, G. (1951). Hormonal influences on glucose resorption from the intestines. I. Methodical principles, daily variations in the absorption of sugar. The proportion between the absorption of glucose and xylose. Acta physiol. Acad. Sci., hung., 2, 435-443.

Howe, P. E. (1921). An effect of the ingestion of colostrum upon the composition of the blood of new-born calves. J. biol. Chem., 49, $115-118$.

Jacobs, F. A., Coen, L. J., and Hillman, R. S. L. (1960). Influence of pyridoxine, pyridoxal phosphate, deoxypyridoxine, and 2,4dinitrophenol on methionine absorption. Ibid., 235, 1372-1375. and Hillman, R. S. L. (1958). Intestinal absorption of the methionine isomers as affected by deoxypyridoxine. Ibid., 232 . 445-451.

Jervis, E. L., and Smyth, D. H. (1959a). The effect of concentrations of amino acids on their rate of absorption from the intestine. J. Physiol. (Lond.), 149, 433-441.

(1959b). Competition between enantiomorphs of amino acids during intestinal absorption. Ibid., 145, 57-65.

- (1960). The active transfer of D-methionine by the rat intestine in vitro. Ibid., 151, 51-58.

Johnston, J. M., and Wiggans, D. S. (1958). The absorption in vitro of alanyl-phenylalanine. Biochim. biophys. Acta (Amst.), 27, 224-225.

Kekwick, R. A. (1959). The serum proteins of the fetus and young of some mammals. In Advanc. Protein Chem., p. 231-254.

Kershaw, T. G., Neame, K. D., and Wiseman, G. (1960). The effect of semistarvation on absorption by the rat small intestine. in vitro and in vivo. J. Physiol. (Lond.), 152, 182-190.

Kertai, P., Feher, I., and Gáti, T. (1956). The role of the ATPcontent of the intestinal mucosa in the absorption of various substances. Acta physiol. Acad. Sci. hung., 10, 33-41.

Kratzer, F. H. (1944). Amino acid absorption and utilization in the chick. J. biol. Chem., 153, 237-247.
Kuroda, Y., and Gimbel, N. S. (1954). Selective disappearance of stereoisomers of amino acids from the human small intestine. J. appl. Physiol., 7, 148-150.

Kutscher, Fr., and Seemann, J. (1901-1902). Zur Kenntniss der Verdauungsvorgänge im Dünndarm. I. Hoppe-Seylers $Z$. physiol. Chem., 34, 528-543.

Laster, L. and Ingelfinger, F. J. (1961). Intestinal absorption-aspects of structure, function and disease of the small-intestine mucosa. New Engl. J. Med., 264, 1138-1148; 1192-1200; 1246-1253.

Lathe, G. H. (1943). The effect of the concentration of different substances in the intestinal contents on their absorption from the small intestine. Rev. canad. Biol., 2, 134-142.

Lin, E. C. C., and Wilson, T. H. (1960). Transport of L-tyrosine by the small intestine in vitro. Amer. J. Physiol., 199, 127-130.

-, Hagihira, H., and Wilson, T. H. (1962). Specificity of the transport system for neutral amino acids in the hamster intestine. Ibid., 202, 919-925.

Loewi, O. (1902). Ueber Eiweisssynthese im Thierkörper. NaunynSchmiedeberg's Arch. exp. Path. Pharmak., 48, 303-330.

London, E. S. (1935). Angiostomie und Organestoffwechsel. AllUnion-Institut-Exper. Med., Moscow.

- and Kotschneff, N. P. (1934). In welcher Form wird Nahrungseiweiss resorbiert? I. Mitteilung. Hoppe-Seylers Z. physiol. Chem., 228, 235-242.

Longenecker, J. B., and Hause, N. L. (1959). Relationship between plasma amino acids and composition of the ingested protein. Arch. Biochem. Biophys., 84, 46-59.

Matthews, D. M. and Laster, L. (1965a). The kinetics of intestinal active transport of five neutral amino acids. Amer. J. Physiol., 208, 593-600.

and Laster, L. (1965b). Competition for intestinal transport among five neutral amino acids. Ibid., 601-606.

- and Smyth, D. H. (1952). Stereochemically specific absorption of alanine from the intestine into the blood-stream. J. Physiol., (Lond.), 116, 20-21P.

(1954). The intestinal absorption of amino-acid enantiomorphs. Ibid., 126, 96-100.

- and Wiseman, G. (1953). Transamination by the small intestine of the rat. Ibid., 120, 55P.

McCance, R. A., Hutchinson, A. O., Dean, R. F. A., and Jones, P. E. H. (1949). The cholinesterase activity of the serum on newborn animals and of colostrum. Biochem. J., 45, 493-496.

- , and Widdowson, E. M. (1959). The effect of colostrum on the composition and volume of the plasma of newborn piglets. J. Physiol. (Lond.), 145, 547-550.

Milne, M. D. (1964). Disorders of amino-acid transport. Brit. med. J. 1, 327-336.

Murlin, J. R., Tomboulian, R. L., and Pierce, H. B. (1937). Absorption of insulin from Thiry-Vella loops of intestine in normal and depancreatized dogs. Amer. J. Physiol., 120, 733-743.

Nasset, R. S. (1957). Role of the digestive tract in the utilization of protein and amino acids. J. Amer. med. Ass., 164, 172-177.

Nathans, D., Tapley, D. F., and Ross, J. E. (1960). Intestinal transport of amino acids studied in vitro with L-(131-I) monoiodotyrosine. Biochim. biophys. Acta (Amst.), 41, 271-282.

Neame, K. D., and Wiseman, G. (1957). The transamination of glutamic and aspartic acids during absorption by the small intestine of the dog in vivo. J. Physiol. (Lond.), 135, 442-450.

- (1958). The alanine and oxo acid concentrations in mesenteric blood during the absorption of L-glutamic acid by the small intestine of the dog, cat and rabbit in vivo. Ibid., 140, 148-155.

Neil, M. W. (1959). The absorption of cystine and cysteine from rat small intestine. Biochim. J., 71, 118-124.

Newey, H., and Smyth, D. H. (1959). The intestinal absorption of some dipeptides. J. Physiol. (Lond.), 145, 48-56.

— - (1960). Intracellular hydrolysis of dipeptides during intestinal absorption. Ibid., 152, 367-380.

(1962). Cellular mechanisms in intestinal transfer of amino acids. Ibid., 164, 527-551. (1963). Specificity of carriers in intestinal transfer of glycine. Ibid., 165, 74-75P.

(1964). Effects of sugars on intestinal transfer of aminoacids. Nature (Lond.), 202, 400-401.

Paine, C. M., Newman, H. J., and Taylor, M. W. (1959). Intestinal absorption of methionine and histidine by the chicken. Amer. J. Physiol., 197, 9-12. 
Parkinson, T. M., and Olson, J. A. (1963). Inhibitory effects of bile acids on the uptake, metabolism and transport of watersoluble substances in the small intestine of the rat. Life Sci., 6 , 393-398.

Parshin, A. N., and Rubel, L. N. (1951). The nature of products of protein digestion that are absorbed from the intestine into the blood. (In Russian.) Dokl. Akad. Nauk. SSSR., 7, 313-315 (abstract in Chem. Abstr., 45, 7206).

Parsons, B. J., Smyth, D. H., and Taylor, C. B. (1958). The action of phlorrhizin on the intestinal transfer of glucose and water in vitro. J. Physiol. (Lond.), 144, 387-402.

Pinsky, J., and Geiger, E. (1952). Intestinal absorption of histidine as influenced by tryptophan in the rat. Proc. Soc. exp. Biol. (N.Y.), 81, 55-57.

Quastel, J. H. (1961). Technics for studies of intestinal absorption in vitro. Meth. med. Res., 9, 273-286.

Ratner, B., and Gruehl, H. L. (1934). Passage of native proteins through the normal gastro-intestinal wall. J. clin. Invest., 13, 517-532.

Reynolds, E. H., Hallpike, J. F., Phillips, B.M., and Matthews, D. M. (1965). Reversible absorptive defects in anticonvulsant megaloblastic anaemia. J. clin. Path., in the press.

Rosenberg, T. (1954). The concept and definition of active transport. Symp. Soc. exp. Biol., 8, 27-41.

Schofield, F. A., and Lewis, H. B. (1947). A comparative study of the metabolism of $a$-alanine, $\beta$-alanine, serine, and isoserine. I. Absorption from the gastrointestinal tract. J. biol. Chem., 168, 439-445.

Schmengler, F. E. (1933). Ưber die Permeabilität getrockneter Kollodiummembranen für Aminosäuren im Vergleich zu organischen Nichtelectrolyted. Pfiügers Arch. ges. Physiol., 232, $591-603$.

Sheff, M. F., and Smyth, D. H. (1955). An apparatus for the study of in vivo intestinal absorption in the rat. J. Physiol. (Lond.), 128, 67P.

Shishova, O. A. (1956). Role of phosphorylation in absorption of amino acids in intestine. Biochemistry, 21, 105-113. (Russian text Biokhimiya, 21, 111-118).

- (1959). The effect of phosphorylation on the absorption of various amino acids. Ibid., 24, 480-485. (Russian text, Ibid., 24, 514-520.)

Smith, E. L. (1948). The isolation and properties of the immune proteins of bovine milk and colostrum and their role in immunity: a review. J. Dairy Sci., 31, 127-138.

Smyth, D. H. (1961a). Intestinal absorption. Proc. roy. Soc. Med., $54,769-773$.

- (1961b). Methods for study of intestinal absorption in vivo. Meth. med. Res., 9, 260-272.

- and Taylor, C. B. (1957). Transfer of water and solutes by an in vitro intestinal preparation. J. Physiol. (Lond.), 136, 632-648.

- , and Whaler, B. C. (1953). Apparatus for the in vitro study of intestinal absorption. Ibid., 121, 2-3P.

Sols, A., and Ponz, F. (1947). A new method for the study of intestinal absorption. Rev. espan. Fisiol., 3, 207-211.

Spencer, R. P., Bow, T. M., and Markulis, M. A. (1962). Amino group requirements for in vitro intestinal transport of amino acids. Amer. J. Physiol., 202, 171-173.

- and Knox, W. E. (1960). Comparative enzyme apparatus of the gut mucosa. Fed. Proc. 19, 886-897.

_- and Samiy, A. H. (1960). Intestinal transport of L-tryptophan in vitro: inhibition by high concentrations. Amer. J. Physiol., 199, 1033-1036.

- (1961). Intestinal absorption of L-phenylalanine in vitro. Ibid., 200, 501-504.

- and Zamcheck, N. (1961). Presence of glutaminase $I$ in rat intestine. Gastroenterology, 40, 423-426.

Stein, W. H., Bearn, A. G., and Moore, S. (1954). The amino acid content of the blood and urine in Wilson's disease. J. clin. Invest., 33, 410-419.

- , and Moore, S. (1954). The free amino acids of human blood plasma. J. biol. Chem., 211, 915-926.

Sugawa, T., Akedo, H., and Suda, M. (1960). Intestinal absorption of amino acids. II. Isotopic studies on the amino acids absorption from the intestine using S35 DL-methionine and C14 DLvaline. J. Biochem. (Tokyo), 47, 131-138.
Sussman, H., Davidson, A., and Walzer, M. (1928). Absorption of undigested proteins in human beings. III. The absorption of unaltered egg protein in adults. Arch. intern. Med., 41, 409-414.

Tapley, D. F., Herz, R., Jr., Ross, J. E., Deuel, T. F., and Leventer, L. (1960). Glucuronide formation in active transport of amino acid and thyroxine analogues by rat intestine. Biochim. biophys. Acta (Amst.), 43, 344-345.

Ussing, H. H. (1957). General principles and theories of membrane transport. In Metabolic Aspects of Transport across Cell Membranes, edited by Q. R. Murphy, pp. 39-56. University of Wisconsin Press, Madison.

Van Slyke, D. D., and Meyer, G. M. (1912). The amino-acid nitrogen of the blood. Preliminary experiments on protein assimilation. J. biol. Chem., 12, 399-410.

$-,-1913-14)$. The fate of protein digestion products in the body. III. The absorption of amino acids. Ibid., 16, 197-212.

Verzár, F., and McDougall, E. J. (1936). Absorption from the Intestine. Longmans, London.

Visscher, M. B., Roepke, R. R., and Lifson, N. (1945). Osmotic and electrolyte concentration relationships during the absorption of autogenous serum from ileal segments. Amer. J. Physiol., 144, 457-463.

Voit, C., and Bauer, J. (1869). Ueber die Aufsaugang im Dick-und Dünndarme. Z. Biol., 5, 536-570.

Wang, H. L., and Waisman, H. A. (1961). Phenylalanine tolerance tests in patients with leukemia. J. Lab. clin. Med., 57, 73-77.

Whaler, B. C. (1955). The metabolism of amino acids by the small intestine. J. Physiol. (Lond.), 130, 278-290.

Wiggans, D. S., and Johnston, J. M. (1959). The absorption of peptides. Biochim. biophys. Acta (Amst.), 32, 69-73.

Wilbrandt, W., and Rosenberg, T. (1961). The concept of carrier transport and its corollaries in pharmacology. Pharmacol. Rev., 13, 109-183.

Wilson, S. J., and Walzer, M. (1935). Absorption of undigested proteins in human beings. IV. Absorption of unaltered egg protein in infants and in children. Amer. J. dis. Child., 50, 49-54.

Wilson, T. H. (1962). Intestinal Absorption, pp. 122-123. Saunders, Philadelphia and London.

(1964). Structure and function of the intestinal absorptive cell. In The Cellular Functions of Membrane Transport, edited by J. F. Hoffman, pp. 215-229. Prentice Hall, New Jersey.

- and Lin, E. C. C. (1960). Active transport by intestines of fetal and newborn rabbits. Amer. J. Physiol., 199, 1030-1032. and Landau, B. R., and Jorgensen, C. R. (1960). Intestinal transport of sugars and amino acids. Fed. Proc., 19, 870-875. , and Wiseman, G. (1954). The use of sacs of everted small intestine for the study of the transference of substances from the mucosal to the serosal surface. J. Physiol. (Lond.), 123, 116-125.

Wiseman, G. (1951). Active stereochemically selective absorption of amino acids from rat small intestine. Ibid., 114, 7-8P.

(1953). Absorption of amino-acids using an in vitro technique. Ibid., 120, 63-72.

_ (1955). Preferential transference of amino-acids from amino-acid mixtures by sacs of everted small intestine of the golden hamster. (Mesocricetus auratus). Ibid., 127, 414-422.

- (1956). Active transport of amino acids by sacs of everted small intestine of the golden hamster (Mesocricetus auratus). Ibid., 133, 626-630.

- (1957). Effects of pyridoxal on the active transport of amino acids by sacs of everted intestine of the golden hamster. (Mesocricetus auratus). Ibid., 136, 203-207.

- (1961). Sac of everted intestine technic for study of intestinal absorption in vitro. Meth. med. Res., 9, 287-292.

- (1964). Absorption from the intestine. Academic Press. London and New York.

_-, Neame, K. D., and Ghadially, F. N. (1959). Effect of sarcoma RD3 on intestinal active absorption of glucose and L-histidine. Brit. J. Cancer, 13, 282-287.

Wolff, J. (1964). Transport of iodide and other anions in the thyroid gland. Physiol. Rev., 44, 45-90.

Wright, R. D., and Wynn, B. (1951). The digestion of protein in the alimentary canal. Austr. J. exp. Biol. med. Sci., 29, 281-284.

Yuile, C. L., O'Dea, A. E., Lucas, F. V., and Whipple, G. H. (1952) Plasma protein labeled with lysine-E-C ${ }^{14}:$ its oral feeding and related protein metabolism in the dog. J. exp. Med., 96, 247-254. 